\title{
Are Environmentalists Altruists? An Empirical Study
}

\author{
Takehisa Kumakawa \\ Creative Engineering Education Center, Nagoya Institute of Technology, Nagoya, Japan \\ Email: kumakawa.takehisa@nitech.ac.jp
}

How to cite this paper: Kumakawa, T. (2020) Are Environmentalists Altruists? An Empirical Study. Open Access Library Journal, 7: e6060. https://doi.org/10.4236/oalib.1106060

Received: January 8, 2020

Accepted: February 18, 2020

Published: February 21, 2020

Copyright $\odot 2020$ by author(s) and Open Access Library Inc.

This work is licensed under the Creative

Commons Attribution International

License (CC BY 4.0).

http://creativecommons.org/licenses/by/4.0/

(c) (i) Open Access

\begin{abstract}
Previous studies on environmental evaluation suggest that women have more altruistic preferences and therefore value the surrounding environment more than men. This study examined the relationship between environmental concerns and altruistic preferences in a simple way. As a result, unlike findings from previous studies, both variables did not correlate with each other. Moreover, gender differences in altruism were confirmed, but those in environmentalism were not. A possible explanation for such discrepancies is that altruistic preferences are context-specific and not invoked until altruistic decisions are defined based on environmental issues.
\end{abstract}

\section{Subject Areas}

Environmental Economics

\section{Keywords}

Environmentalism, Altruism, Gender Differences, Online Survey

\section{Introduction}

Altruism has been regarded as one of the most closely related preferences in environmentalism up to the present. Theoretical works suggest that altruistic preferences sustain environmental concerns, subsequently leading to pro-environmental behavior (Merchant [1]; Stern, Dietz, \& Kalof [2]; Stern \& Dietz [3]). In a similar way, experimental works on the governance of common pool resources imply that the more altruistic subjects are, the more likely they are to act for the group's interests (Ostrom et al. [4]). The correlation between altruistic preferences and environmental concerns seems to be natural because many environmental problems involve decisions affecting the welfare of other people, including the maintenance of common pool resources. However, not enough evidence 
has been provided for this explanation thus far. This is partially because most previous studies define altruistic preferences within the context of environmental protection, which has been their main focus. Unlike prior research, this study measures altruistic preferences in a context that is totally independent from environmental issues, and explores the connection between altruistic preferences and environmental concerns in a simple way.

\section{Survey Design}

The survey was administered to Japanese respondents online. Of all 630 participants, the male-to-female ratio was 1:1. Except for this aspect, participants were randomly sampled, regardless of their individual attributes such as age, income, and civil status.

\subsection{Measuring Environmental Concerns}

Individuals' environmental concerns were gauged via a quiz that tested their understanding of local and global environmental problems. ${ }^{1}$ The quiz was based on the Tokyo Chamber of Commerce and Industry's Certification Test for Environmental Specialists, one of Japan's most common tests on environmental awareness. Respondents answered 10 questions, each of which contained two options they could choose from. Their respective scores (hereafter referred to as the $E$-score) ranged from 0 to 10 (depending on the number of correct answers) and represent the extent of their environmental awareness.

\subsection{Measuring Altruistic Preferences}

Altruistic preferences were quantified using the psychological scale developed by Rushton, Chrisjohn, and Fekken [6]. The scale was based on the depiction of people described within the context of Japanese culture. The scale ranged from 10 to 50; a higher score indicated a more altruistic preference.

\section{Results}

\subsection{Gender Differences}

As a preliminary check, Table 1 lists the descriptive statistics of $E$-scores and altruistic scores by gender. As shown, gender differences were observed in the mean altruistic scores, but not in the mean $E$-scores. The mean altruistic score of females was greater than that of males, which was statistically supported. Table 2 shows the results of the Wilcoxon rank-sum test and the t-test for gender differences. In both tests, the altruistic scores of women were significantly different from those of men at the $1 \%$ level. In contrast, such discrepancies based on gender were not confirmed in $E$-scores at the $10 \%$ level.

Gender disparities in environmentalism are a major topic in the literature on environmental evaluation. The literature typically implies that women have

${ }^{1}$ Unlike this study, Kotchen and Reiling [5] measured individuals' environmental attitudes using the New Ecological Paradigm scale. 
Table 1. Descriptive statistics of $E$-scores and altruistic scores by gender.

\begin{tabular}{ccccc}
\hline & \multicolumn{2}{c}{$E$-score } & \multicolumn{2}{c}{ Altruistic score } \\
\cline { 2 - 5 } & Males & Females & Males & Females \\
\hline Mean & 6.429 & 6.419 & 23.702 & 25.422 \\
Standard deviation & 1.303 & 1.362 & 7.361 & 6.870 \\
Minimum & 1 & 3 & 10 & 10 \\
Maximum & 10 & 10 & 45 & 43 \\
Observations & 315 & 315 & 315 & 315 \\
\hline
\end{tabular}

Table 2. Tests for gender differences in the $E$-score and altruistic score.

\begin{tabular}{ccc}
\hline & $E$-score & Altruistic score \\
\hline Wilcoxon rank-sum test & 0.453 & $3.306^{*}$ \\
t-test & 0.090 & $3.033^{*}$ \\
\hline
\end{tabular}

Note ${ }^{\star}$ denotes significance at the $1 \%$ level.

more altruistic preferences and thus value the surrounding environment more than men (Dietz, Kalof, \& Stern [7]; Arnocky \& Stroink [8]). Unlike that suggestion, this study did not observe gender differences in environmentalism.

\subsection{Multiple Linear Regression}

Next, a multiple linear regression was conducted to examine variables that influenced the $E$-score, which was a dependent variable. The independent variables that were adopted included altruistic score, age, gender, and employment. In addition to gender, employment was also a dummy variable; a score of 1 was assigned if the respondent was a full-time worker, and 0 if otherwise. Table 3 summarizes the results. Apparently from the table, none of the independent variables were significant at the $10 \%$ level, except for the constant term. As an alternative way to confirm these findings, Spearman's rank correlation coefficients were calculated, as shown in Table 4. As we can see, all the coefficients were quite consistent with the outcomes of the multiple linear regression. Consequently, using pooled data between men and woman, it was found that altruistic preferences do not significantly impact environmental concerns.

\section{Concluding Remarks}

This study examined the relationship between environmental concerns and altruistic preferences in a simpler way than prior investigations. Unlike the findings of previous research, both variables did not correlate. Moreover, gender differences in altruism were confirmed, but those in environmentalism were not. A possible explanation is that altruistic preferences are context-specific and not invoked until altruistic decisions are defined based on environmental issues. Another possibility is that there might be a cultural difference between the countries in which the sampled populations live, although the sample size of this 
Table 3. Results of multiple linear regression.

\begin{tabular}{ccc}
\hline Independent variable & Coefficient & Standard error \\
\hline Constant & $6.166^{*}$ & 0.298 \\
Altruistic score & 0.054 & 0.008 \\
Age & -0.001 & 0.004 \\
Gender & -0.018 & 0.116 \\
Employment & 0.022 & 0.116 \\
\hline
\end{tabular}

Note ${ }^{*}$ denotes significance at the $1 \%$ level.

Table 4. Spearman's rank correlation coefficients.

\begin{tabular}{cc}
\hline & $E$-score \\
\hline Altruistic score & 0.047 \\
Age & -0.007 \\
Gender & -0.018 \\
Employment & 0.007 \\
\hline
\end{tabular}

Note: None of the correlation coefficients are significant at the $10 \%$ level.

study is too small to draw a conclusion. This could be a possible path for future research.

\section{Acknowledgements}

This research was supported by a Grant-in-Aid for JSPS Fellows (No. 231657) from the Japan Society for the Promotion of Science (JSPS).

\section{Conflicts of Interest}

The author declares no conflicts of interest regarding the publication of this paper.

\section{References}

[1] Merchant, C. (1992) Radical Ecology: The Search for a Livable World. Routledge, New York, NY.

[2] Stern, P.C., Dietz, T. and Kalof, L. (1993) Value Orientations, Gender, and Environmental Concern. Environment and Behavior, 25, 322-348. https://doi.org/10.1177/0013916593255002

[3] Stern, P.C. and Dietz, T. (1994) The Value Basis of Environmental Concern. Journal of Social Issues, 50, 65-84. https://doi.org/10.1111/j.1540-4560.1994.tb02420.x

[4] Ostrom, E., Dietz, T., Dolsak, N., Stern, P.C., Stonich, S. and Weber, E.U. (2002) The Drama of the Commons. National Academy Press, Washington, D.C.

[5] Kotchen, M.J. and Reiling, S.D. (2000) Environmental Attitudes, Motivations, and Contingent Valuation of Nonuse Values: A Case Study Involving Endangered Species. Ecological Economics, 32, 93-107. https://doi.org/10.1016/S0921-8009(99)00069-5

[6] Rushton, J.P., Chrisjohn, R.D. and Fekken, G.C. (1981) The Altruistic Personality 
and the Self-Report Altruism Scale. Personality and Individual Differences, 2, 293-302. https://doi.org/10.1016/0191-8869(81)90084-2

[7] Dietz, T., Kalof, L. and Stern, P.C. (2002) Gender, Values, and Environmentalism. Social Science Quarterly, 83, 353-364. https://doi.org/10.1111/1540-6237.00088

[8] Arnocky, S. and Stroink, M. (2010) Gender Differences in Environmentalism: The Mediating Role of Emotional Empathy. Current Research in Social Psychology, 16, $1-14$. 